\title{
The Home Front: The Yukon's Economy During the First World War
}

\author{
Sally Robinson \\ Independent Historian
}

Abstract: The Yukon-and Dawson City in particular-saw a decline in population and gold production between 1915 and 1918, and there was a continued decline in fortunes into the 1920s. Some of the economic woes were due to a shift from labour-intensive mining to large-scale dredging and hydraulic mining. Then whole creeks were abandoned when placer miners went to war. The Yukon economy was largely dependent on a few large companies that were adversely affected by war-related inflation and the rise in production costs, a demand for metals and minerals other than gold, and a shortage of equipment and labourers. Gold production fell during the war and there was no other industry to take its place. The Yukon's federal operating grant was reduced by more than half in 1918, reflecting the territory's slump in production. The Yukon government had a limited ability to hire returned soldiers for scarce labour or office positions. The final blow to the economy of what was then Yukon's largest community was the sinking of the SS Sophia and the loss of many prominent Dawson citizens. After the war, services were inefficient, gold was fixed at a low price, and expenses were high. Large tracts of valuable mining land were owned by companies no longer interested or able to mine it. The First World War was not directly responsible for the Yukon's downturn in fortune, but the effects of the war certainly hastened the decline. This article is part of a special collection of papers originally presented at a conference on "The North and the First World War," held May 2016 in Whitehorse, Yukon.

The Northern Review 44 (2017): 31-49 
Yukon's economy is based on mining with help from tourism, and this was also true during the First World War. There is a difference in that today's resource extraction is not wholly based on gold placer mining, as it was between 1914 and 1918. Mining is a cyclical industry with its health depending on the price of commodities - which often reflect the stability of international politics and policies. Yukon's economic and political prospects went from full speed ahead in 1914 to an almost full stop in 1918. The question is how much of that downswing in fortune was due to the natural cycle, and how much was due to the effects of the First World War?

We can start with the certainty that there was no planning or foresight for economic diversification in the Yukon before the war. To be fair, although the Yukon Territorial Council had elected members, council decisions could be vetoed by the Yukon Commissioner who answered to the federal minister of the interior. Advice from the federal government remained the same from the start of the Klondike Gold Rush in 1898-get in, get what you can fast, and then get out. The main action from Ottawa was to support capitalized mining - that was seen as the future of the Yukon. Twelve-year hydraulic leases, of one to five miles (1.6 to $8 \mathrm{~km})$ in length and one mile $(1.6 \mathrm{~km})$ deep, were granted to successful applicants who wanted to pursue large-scale mining. The most generous grant was given in 1901 to the British mining entrepreneur A.N.C. Treadgold, who already had a stock of unclaimed land and lapsed claims purchased for his British backers. ${ }^{1}$

By 1914, large-scale dredging and hydraulic mining dominated the scene in the Klondike. Scores of men were still quietly working individual claims throughout central and southern Yukon, but they were not big employers. The prevailing impression was that individual mining would soon be a thing of the past, and that most of the rich ground was either possessed by large companies or at least bonded to them. ${ }^{2}$

Yukon gold production had increased in 1908, the first time since 1900, and it rose slowly and steadily from 1908 to $1914 .^{3}$ The year 1913 saw peak gold production by Yukon dredges, when the Yukon Gold Company and Canadian Klondyke Mining Company together mined about nine tons. ${ }^{4}$ There were thirteen dredges working in the Yukon, including Canadian Klondyke's four and Yukon Gold's seven. The big companies operated with American and British capital. The Guggenheims, an American family known for their global success in mining and smelting, had invested \$12 
million in the Yukon Gold Company by $1908 .{ }^{5}$ Joe Boyle's Canadian Klondyke dredging company was initially backed by the Rothschilds, a family of international financiers; it became a complicated labyrinth of agreements that often landed Boyle in the courts. Yukon Gold and Canadian Klondyke were public companies-and they were the largest operations in the Klondike. By 1914 they each had about sixty skilled mechanics in their machine shops. Yukon Gold was yearly employing a total average of 700 men, and Canadian Klondyke was hiring about $150 .{ }^{6}$

At the beginning of the war, large-scale mining had increased gold production, but it was not sustaining the economy as the gold rush labour-intensive mining had done. ${ }^{7}$ Small placer operations, sometimes with only the owner and a few workers, were mostly located in goldfields and mining camps outside the hub of Bonanza and Eldorado creeks. Older mining camps and proven creeks in the Fortymile and Sixtymile drainages nearer the Alaskan border had received a new rush of eager prospectors and miners, as did the Stewart River district in central Yukon, with Mayo as the supply centre, and the Livingstone Creek area just north of Whitehorse. Resources in the Kluane Lake district to the west were looked at again, as was the Wheaton River and Montana Mountain area to the south. These small operations were not capital intensive and did not use enough equipment or supplies to support the large community and infrastructure that had been built up during the gold rush.

Dawson, the Yukon's largest population centre, had become increasingly dependent on the health of the large dredging and hydraulic mining companies. ${ }^{8}$ The big companies imported their own machinery, and also imported employees and housed them in mainly seasonal camps. Many Dawson businesses were forced out of business as a result. The Klondike Thawing Machine Company, for example, was established to sell dredging parts and equipment to independent miners. It started buying out failing Dawson businesses in 1910 and by 1913 was a general store selling Ford cars and stretching boards for beaver pelts. ${ }^{9}$ One of the oldest trading companies and supply businesses closed its Dawson store in 1912 as the town's transportation facilities became more important than its mercantile function. ${ }^{10}$

Dawson's infrastructure was threatened even before the war-another early sign that the Yukon's economic dependence on a few big companies signalled a coming decline, and that the war would only indirectly contribute to the downswing. In 1913 Joe Boyle's mining concession company leased the business of the locally-owned Northern Light, Power and Coal Company, which ran the Dawson electrical, water, and telephone 
systems. ${ }^{11}$ This happened in February, one of the darkest, coldest months of the year in the Subarctic, and one of the months when the threat of fire from faulty heating systems is highest. Fire is the biggest enemy of a northern town composed of wooden buildings. In 1913 the Yukon's Royal Northwest Mounted Police commander reported that most of the police buildings were fire traps - frame buildings with interior walls lined with cotton that was papered over. Dawson had suffered from several devastating fires over the years, and the Dawson detachment burned in 1912 destroying all records in the building. The police responded to the lack of a good hydrant system by tearing down all abandoned or derelict buildings in the police compound. ${ }^{12}$

Concerned residents organized, worried about continued pressure in the Dawson fire hydrants, high rates, and poor service. They petitioned the Yukon Territorial Council to support the city in purchasing the utility company and then learned that Dawson was not a legal entity that could borrow money. ${ }^{13}$ Dawson had lost its status as a city in 1902 and never bothered reorganizing, instead depending on the Yukon Council to manage the community. As great as was the need, no one wanted to create another level of bureaucracy and suffer the taxes that would follow.

Newly appointed Commissioner George Black came up with a solution to the problem, which did not involve an increase in taxes. A bill, passed at the end of March 1914, created a system of municipal government in which the city was reincorporated, but the commissioner became the chief executive officer in a city council of himself and four Yukon councillors who represented two Dawson constituencies. This city council would have all the powers of the original council, plus the authority to raise or borrow money to buy and operate the water, light, and power plants.

The biggest news of 1913 happened when the White Pass \& Yukon Route company purchased the entire Yukon River fleet of their main competition. The miners were worried about the inevitable rise in freight costs after the rate war that drove the competition out of business. This was not the only change in transportation infrastructure. The Klondike Mines Railway closed down in July 1914. Even before 1910, the railway's expenditures were almost double revenues, and the company was requesting grants and financial aid from the Yukon council. The dredging companies used the railway to freight camp supplies, parts, and equipment. There was a low volume of passenger traffic, and by 1913 the only section of line in use was the twelve miles $(19 \mathrm{~km})$ between Dawson and the small Bonanza valley community of Grand Forks. ${ }^{14}$ Roads in the 
creeks were improving; the companies that could afford it were buying their own freight vehicles.

An increased use of motorized vehicles played a role in closing down the Klondike Mines Railway, but this was not the whole story. By the fall of 1913, three dredges had moved out of reach of the rail line. By that time, the main occupation for the railway was hauling wood for the steamthawing operations ahead of the dredges. Income from passenger service was practically nil by $1914^{15}$ as the big mining companies owned a lot of the claims along Bonanza Creek, the route of the rail line. ${ }^{16}$ And this was not the only creek that was depopulated. The Gold Bottom social club, in the Hunker Creek drainage, closed for good in 1913.

Despite these and other troubling indicators, the Yukon economy was doing well in 1914. The dredging and hydraulic companies were working at full capacity. There was an abundance of water to help the large-scale mining companies and individual miners. ${ }^{17}$ The year before had been a record for the length of the mining season, and 1914 was even longer as heavy rain continued to fall daily between June and the end of September. ${ }^{18}$ Individual miners on the placer creeks were at least making good wages. ${ }^{19}$ Many Yukoners, especially the Indigenous peoples in the region (primarily Tr'ondek Hwech'in), were trapping instead of mining, and fur prices were high that year. Indigenous trappers were making good money although unemployed Yukoners saw the opportunity to start their own traplines. Fox farming was also doing well in 1914 and Indigenous trappers could make good money selling captured wild foxes and kits to the farms. One man sold his captured foxes for $\$ 1,000$ and bought a gasoline launch. ${ }^{20}$

The police blamed an increase of intoxication in the Indigenous community on the rise in their buying power. The government was worried about the depletion of game, and so a territorial ordinance was passed in 1914 prohibiting the exportation of any live fox not born in captivity, or which had not been in captivity for at least two years. It also prevented the hunting, killing, or taking of any fox under one year of age between 1 April and 1 June. The 1914 Mounted Police report commented that this would prevent the depletion of wild foxes. What was not said in the police report was that the ordinance would also take care of the perceived problem of excess cash in the Indigenous community. ${ }^{21}$ Commissioner Black and two territorial councillors were among the directors of the Colwell Fur Farms. The new law did favour the Colwell Farms, which could easily keep wild foxes for two years before selling them. ${ }^{22}$ Democracy in the Yukon in 1914 was freestyle. 
The year 1914 was a good year but 1915 was tough, and the first year that the effects of the war became apparent. There was a drought at the beginning of the mining season. The big companies were only able to operate the hydraulic workings on a small scale, so there were unemployed men during the summer. ${ }^{23}$ Rains late in the season and a warm fall meant the operations could continue later in the season, but it is doubtful that the best men were still available for hire. The population, heavily centralized in Dawson, had declined with the change from labour-intensive mining to capital-intensive mining starting around 1906. A redistribution of the Klondike area population started in 1909 with immigration to Dawson exceeding emigration and the rate of change remained relatively constant through 1910. ${ }^{24}$ In 1911 the Yukon population had declined from a gold rush high of about 30,000 people to about 8,500. Many of these people were seasonal workers. Historian Hal Guest collected population data for Dawson that suggests a four-year turnover rate in excess of $50 \%$. The numbers remained relatively consistent between 1911 and 1915 when the population started to decline..$^{25}$ This was a combination of less available employment and fewer employable men who were spared by the war. By 1921 there were fewer than half the people recorded in $1911 .{ }^{26}$

The numbers of Mounted Police in the Yukon remained stable through the war, although the force was not without its problems. The Yukon was relatively important in the Canadian economic landscape, and the force increased from fifty in 1910 to fifty-three in 1914. ${ }^{27}$ The commander wanted at least fifty men in case something happened in the dredging and hydraulic camps, but also to man the Yukon River community at Selkirk, the trading post and Southern Tutchone community at Champagne, the small mining camp at Livingstone, and a community of excited prospectors in the Sixtymile. ${ }^{28}$

On the outbreak of war with Germany and Austria, many individuals, especially reservists, enlisted right away. Men left to join up in their home country or Canadian city. Many in the Mounted Police immediately volunteered for service but were told that the force would not be going to the front as a regiment. ${ }^{29}$ Many enlisted individually if they could, even though the police were asking recruits to join the local force for one year of service with good terms offered. The Yukon force was never under strength, but the good terms were not an enticement in the face of overwhelming patriotism. Joe Boyle, the general manager of the Canadian Klondyke Mining Company, offered a more exciting opportunity by equipping a battery of fifty men with uniforms and quick-firing guns for service at the front. Boyle's men took a sternwheeler out of Dawson just a 
few days before navigation closed for the winter in $1914 .^{30}$ Among them were twelve former Mounted Police. ${ }^{31}$

The year 1914 was a hard year for Joe Boyle. He had hoped to get to Dawson to inspect his recruits on the day they left Dawson, but one of his largest dredges sank that morning and he became otherwise occupied. His company, Canadian Klondyke, hired some men to right the capsized dredge and repair it so the dredge did some work in 1915, but the $\$ 150,000$ expense was a drain on the company's profit. ${ }^{32}$ The company had received another economic blow in November 1914 when the judgment delivered in a long-standing law suit and counter claim went against them at a cost of $\$ 11,700 .{ }^{33}$ Also, the changes that the Yukon was already experiencing were accelerated by the loss of skilled workers, a diversion of interest by the financial backers, and a rise in production costs, all of these directly or indirectly caused by the war.

The gold standard, a commitment by many countries to fix the price of their money to a specific amount of gold, was widely followed from the late 1800s to 1933. But it broke down during the First World War as governments resorted to inflationary measures to fund their war efforts. A version of the standard remained in place, which kept gold fixed at a price at US \$20.67 per troy ounce. This was a serious deterrent for gold miners, large and small, who had to deal with the war-related inflationary rise in production costs. Capital funding for gold mining was scarce when the war created an increased need and price for copper, lead, and antimony. Gold placer mining output was about $\$ 400$ million in 1916, down about $\$ 300,000$ from 1915, and comments about Dawson's future were not optimistic. The dredges working in the Bonanza Creek valley were gradually moving to poorer ground in outlying locations, and the last dredges working on Bonanza Creek expected to work through the valley by 1918 .

The brightest spots in the Klondike mining scene were the hydraulic operations. This was a cheaper, less-labour intensive way to mine than even the dredges; and the infrastructure, although aging, was already in place. In 1916 numerous hydraulic plants in various creeks in the Klondike district, plus the hydraulic operations of the Yukon Gold Company, comprised one of the largest undertakings of this kind in the world. Over three million cubic yards were handled by Yukon Gold each season for five months. ${ }^{34}$ Yukon Gold's placer hydraulic operations were still mining rich ground, but the forecast of reserves was several years, not several decades. ${ }^{35}$ Even the hydraulic mining was dependent on the health and interest of the owners and financial backers. Yukon Gold 
was the Guggenheim's first public company and it never brought them the expected returns so they were turning to other mining enterprises, especially copper, in places outside the Yukon.

Joe Boyle left for the war in Europe in 1916 and this marked the start of the collapse of his corporate empire. His Canadian Klondyke companies were in default to Granville Mining in July 1916. Granville Mining went into receivership in April 1917 and Boyle's dredges operated under receivership until 1921. ${ }^{36}$

The big companies, even when they experienced decreased activity, still held the majority of the rich ground in the Klondike, so medium-sized mining operations looked to develop areas farther from Dawson. The rise in price for commodities other than gold also benefited regions outside of Dawson. The Silver King mine in the Mayo region continued to ship leadzinc-silver ore out of the territory until 1917 when the high-grade material was exhausted. The claims were sold for over a quarter of a million dollars in 1916, and the new American owners planned a large-scale mine. ${ }^{37}$ Mines take time to develop and nothing really happened until the 1920s. The Whitehorse area profited from the war as copper prices were rising and the locally-owned mines did very well. ${ }^{38}$ Pueblo Mine was the largest, shipping out an average of \$80,000 worth of ore a month in $1916 .{ }^{39}$ The smaller Grafter mine shipped out about \$230,000 worth of copper ore between 1915 and 1917. ${ }^{40}$ Capitalists outside the Yukon expressed interest in several mines south of Whitehorse when the mines' antimony was assayed within $2 \%$ of the value required by the war office. ${ }^{41}$

But gold was still the Yukon's economic driver, and after the richest placer areas were depleted there was nothing to replace its role. Yukon's gold production in 1918 was $80 \%$ of that in $1912 .{ }^{42}$ The Yukon Council had limited ability to affect the economy, other than hiring for projects like road development and office jobs, and with the decline in population and the changes in the mining industry there was less need.

Yukon merchants claimed that 1915 was the worst economic year on record and this was despite the fact that 700 more tons of merchandise were brought to Dawson than in 1914, and amounts shipped out exceeded the previous year's by 300 tons. The big companies were buying their own supplies directly and bypassing the local merchants. ${ }^{43}$ The cost of drugs and patent medicines rose in 1915, and 1916 saw some articles double or triple in price, while others became unobtainable. ${ }^{44}$ The domestic market was not large enough to support the local businesses as the population was much reduced due to the war enlistment and a lack of employment opportunities in the early 1915 season. The police superintendent also 
surmised that residents had been practising frugality in the twelve months since war was declared. ${ }^{45}$ The shipping rates charged by the White Pass \& Yukon Route rose in 1916, and the Yukon was importing fewer vegetables. ${ }^{46}$

This was not a big problem in itself as Dawson agriculture was far past the experimental stage; northern celery and cabbage were larger and had more flavour than southern ones, and all native-grown vegetables were available all year round. ${ }^{47}$ There was an almost steady increase in the land under cultivation between 1900 and 1915, most of it within a hundred miles of Dawson..$^{48}$ But then H.B. Welsh left the country in 1916 saying that the war had stagnated everything and there was no future for his farm. ${ }^{49}$ Farm workers were not doing well either. One large truck farm was paying their hands $\$ 2.75$ a day in 1916 when wages in Dawson were as high as $\$ 5$ to $\$ 7 .{ }^{50}$ Non-commercial vegetable gardens were common and helped to cut down on household expenses. ${ }^{51}$ Yukoners also had the option to hunt for food to supplement their purchases from the merchants. The 1916 migration of barren-ground caribou passed within a few miles of Dawson, and it seemed everyone in town took advantage of this to get fresh meat for the winter. ${ }^{52}$

Dr. Roche, the Canadian minister of the interior, visited the Yukon in June 1916 and reported to the newspapers that he was now better able to understand Yukon's financial and other matters. ${ }^{53}$ This was not the good news it initially appeared to be. Federal support for economic growth was already lacking for the territory, and a drastic cut in funding was to come in $1918 .{ }^{54}$

Meanwhile, George Black had received a commission as captain in the Yukon Expeditionary Force and in 1916 he recruited a company of 275 men. The loss of the 1916 enlistees had a noticeable effect as the role of enlisted read like a Yukon who's who. Black was the Yukon Commissioner and two of the Yukon council members also enlisted. Black's mansion-like residence and also his office were left vacant. The first of Black's recruits were under the leadership of Lieutenant Gordon Hulme who had been an accountant with the light and power company and, later, the Dawson City Water and Power Company. ${ }^{55}$ Lieutenant John McLennan was a long-time Yukoner, a former Mounted Police officer and a community leader. ${ }^{56}$

Yukon's permanent residents were leaving and the numbers coming in were declining as well. Between 700 and 1,000 Yukoners enlisted in the war. This is a hard number to pin down because of the fluid nature of the Yukon population. Newspaper articles and reports included men from nearby British Columbia, recent seasonal workers, and long-time 
Yukoners who had settled outside the territory either working or going to school. ${ }^{57}$ Many self-identified Yukoners recorded in the government enlistment records had no next of kin in the Yukon and were born in countries outside of Canada. Some of the lowest-paid men could not afford to leave. About fifty Montenegrins contacted their country's recruiting office in New York, offering to enlist if their passage out could be paid. They were still in the Yukon in 1915, mining and prospecting. ${ }^{58}$

The Klondike Gold Rush had attracted thousands of people from outside Canada, and the Yukon continued to have a transient population of many nationalities. In 1916 there were again fewer than the usual numbers of men coming in for work in the spring and fall. ${ }^{59}$ The vast majority of them were American, with small numbers from Ireland, Norway, Sweden, and elsewhere in Canada. ${ }^{60}$ Another clue to the mix of nationalities in the Yukon was the list of seventy-one prisoners noted by the police in 1916. They included Canadians, Americans, English, Finlanders, Swedes, Germans, Irish, Scots, French, a lone Norwegian, and one Peruvian. A German naval reservist was sentenced to four months of hard labour for being drunk and uttering seditious language. He was interned at the end of his sentence. ${ }^{61}$ Citizens of enemy countries were not allowed to acquire mining claims during the war. This restriction was not removed until $1920 .{ }^{62}$

Some with German ancestry had a hard time in Dawson during the war, and not only those uttering seditious statements. In the winter of 191516, the British Empire Club was formed in Dawson to uphold the cause of Great Britain by exposing German sentiments in the home population and discouraging anything that might assist the enemy. Club members persuaded most of the big companies to employ only those in sympathy with the Allied cause. The Yukon's police superintendent thought the club had done a certain amount of good. ${ }^{63}$ But he might have reconsidered after the club refused a membership application from Harold Blankman, the Yukon court stenographer. Blankman was a naturalized British subject born in California, and after he accused his accusers of slander, the police had to investigate the club members. ${ }^{64}$ Usually the police were prosecuting suspected aliens, not overly-loyal Brits. Silesian-born Paul Guder was detained during the First World War and his guns taken away. After his release he moved to the Pelly River region where his nationality was of little consequence. ${ }^{65}$ Ernie Schink emigrated from Germany and came to the Yukon in 1898. He and Andrew Rystogi, a Polish emigrant and also a Klondike stampeder, owned the Occidental Hotel, which became a watering hole for Dawson's Slavic population; Schink later bought a 
grocery store. He was an upstanding Dawson businessman. During the war, neighbours of Slavik or German descent were viewed with suspicion and their businesses boycotted. Ernie's daughter and a friend were told they were not welcome at Sunday school. Schink was not able to make a living and so he and a partner bought a coal mine near Carmacks. For several years he delivered coal to Dawson, primarily to the government buildings and the hospital. ${ }^{66}$

By 1917, Dawson's decline in population and status was evident. Polk's 1917 Alaska-Yukon Gazetteer puts Dawson's population at only 2,500 people. One resident said that morale was bad and that depreciation had occurred in the twelve months before the spring of 1917. He blamed the war. ${ }^{67}$ But the decline in Yukon's fortunes started well before the war began.

The list of failed businesses after 1916 is long. Some of the smaller large-scale dredging companies went into receivership in early 1917 followed by Boyle's Canadian Klondyke Mining Company in January $1918 .{ }^{68}$ The failures resulted from a war-related shortage of machinery, restrictions on capital investment, and a declining market for gold ${ }^{69}$ Nor could Yukoners depend on traditional occupations. Fur prices declined after war was declared, and were at their lowest in the spring of 1916. Only a few of those who had lost money in fox farming recovered. Indigenous trappers faced competition from White trappers who, the police reported, treated trapping as a business and put in longer trap lines. In 1917 the police reported that they were increasing relief to Indigenous people every year. ${ }^{70}$

The Yukon was definitely not the happy place it had arguably been in 1914. In November 1916, the Mounted Police were relieved of police duties in Alberta, Saskatchewan, and Manitoba and they reorganized in 1917 to focus on patrolling the international border and supervising enemy nationals. ${ }^{71}$ The force remained the only police in the Yukon and their work in Dawson included preventing the exit of men drafted under the federal Military Service Act, and registering aliens and monitoring their movements. ${ }^{72}$ The third wave of Yukoners that went to war in 1918 numbered about eighty draftees including miners, steam engineers, dredge workers, and at least four Japanese cooks.

In the fall of 1918, the federal operating grant to the territory was reduced by about $58 \%$, and the Yukon Territorial Council was amended to include just the Gold Commissioner and three councillors, only one of whom represented Dawson. The city council ceased to exist and Dawson once again fell under the jurisdiction of the Yukon Council with no 
ability to control its utilities. The police took over grading the streets and collecting the garbage. ${ }^{73}$ The number of territorial employees was reduced, the territorial treasurer and secretary became one position, and the position of legal advisor was abolished. The territorial survey branch was hardest hit by the reductions in staff, and the branch that planned Yukon roads no longer existed by 1919. ${ }^{74}$ Dawson's loss of status also reduced large company taxes. Their proportion of the city's tax base rose with a decrease in population and they increased their relative power and influence with the government. ${ }^{75}$ Dawson needed saloons to operate as they were a large part of the tax base, and this is the main reason that Dawson remained wet when the rest of the country was voting for prohibition.

The 1918 sinking of the SS Sophia, with 125 Dawson residents, is often pinpointed as the critical blow to Dawson's and Yukon's fortunes, and it certainly played a role. But at least two long-time-Yukoner business owners who drowned on the ship had already sold their businesses, in light of the economic downturn, and were leaving the Yukon for good. ${ }^{76}$

Whole creeks were abandoned throughout the Yukon when independent miners left for the war. ${ }^{77}$ The war ended on 11 November 1918, but not all Yukoners were immediately free to return home. Miners with few industrial skills were released first, as were those who volunteered early in the war. Most of the men were back by the end of 1919. ${ }^{78}$ A March 1918 meeting to organize a welcome for returned soldiers also had a more serious topic. It was thought that the returned soldiers should be informed of the Yukon work situation and advised of the existing conditions. ${ }^{79}$ In fact, conditions in the Yukon were likely well known by then. Only about 200 of the Yukon soldiers returned to the Yukon. ${ }^{80}$

Many of those returned soldiers did not return to mining, although their rights had been protected. Up until the war, the small-scale miners spent a lot of their free time accusing the government of a lack of support, and Ottawa was certainly biased toward the large-scale miners, especially in deciding what comprised abandonment. Claims that were abandoned could be picked up by the industrial miners who needed large tracks of land for their hydraulic and dredging equipment, but that changed during the war. An Order in Council dated 28 October 1914 granted concessions to any person with Yukon mining property who had been accepted for and continued in service with the British or Allied forces. Claim holders were permitted to hold their claims free from the risk of cancellation, owing to failure to comply with any of the requirements or regulations, until six months after the final termination of war and the final declaration 
of peace by Britain. ${ }^{81}$ An official amendment to the Yukon Placer Mining Act was passed on 15 April 1915. ${ }^{82}$

The date of the final declaration of peace was set at 10 January 1920 and the Gold Commissioner was informed that the protection offered to veterans would terminate on 10 July $1920 .{ }^{83}$ After this date, the returned soldiers with mining rights would need to do their assessment work as required by the Yukon Mining Act. ${ }^{84}$ The Gold Commissioner chose to understand that this meant the veterans had a year after July 10 to do the work necessary to keep their claims active, and that all of this work would fall due on the same day. ${ }^{85}$ This was more protection than the department of the interior had intended. The minister had actually ruled that the claims were in good standing to the anniversary date of the original grant. The commissioner was called to account for his ruling and he replied that, although he had been mistaken, to rectify his ruling would "result in a hopeless muddle." ${ }^{\prime 86}$ His ruling was allowed to stand. In this case, the Yukon was able to benefit from being so far from Ottawa.

In fact, the situation was still chaotic. Some recorded owners of claims enlisted without advising the mining recorder of their actions, and the claims were recorded as having lapsed. In some cases, these claims had been granted to other miners who had developed what they thought were their claims during the war. The department of justice ruled that the returned soldiers would be allowed to work their claims as if no relocation had been given and the rights of the relocator would be subordinate to those of the original grantees. ${ }^{87}$ No one was happy as the affected veterans lost the gold that had been mined, although they gained from the development work done on their claims by someone else.

In any case, gold mining was not as appealing as it once had been. Costs remained high and the value of gold was low. Most of the returned men wanted employment. In 19 June 1918 Gustave Vaulaire wrote, with beautifully clear handwriting, to apply for a position with the government as a messenger, watchman, or janitor. He had arrived back in March, the second soldier to return, and feared that he would be the last one hired. He reported "my situation is most critical, and the winter is coming." 88 Returned soldiers were petitioning the government to hire them wherever possible. Government worker J.B. LeClaire was transferred to Ottawa by the department, and a letter asking that his position be given to a disabled soldier was met with the reply that LeClaire had been transferred because the position was no longer staffed. ${ }^{89}$ Some went as far as suggesting that the government should fire single men who had not seen service in preference to hiring married returned soldiers. Returned soldiers McCarter, Frame, 
and Johnston were on a committee to appeal to the government. They wrote to the gold commissioner to arrange a meeting with government employees to discuss the problem. ${ }^{90}$

There is no indication that the situation changed. There were fewer jobs than had been available before the war. ${ }^{91}$ The policies of the Yukon government were set in faraway Ottawa, but the Yukon government was called to account. A resolution was created and sent to the gold commissioner from the Dawson branch of the Great War Veterans Association in July 1919 after several returned disabled or partially disabled soldiers were discharged from local government employ for reasons unknown. ${ }^{92}$ The Department of Soldier's Civil Re-establishment responded that returned men received a fair share of the local government road work, although that was much reduced. Many returned soldiers worked on the territorial roads during the summer of 1919. During the winter of 1919-1920, when work was scarce for all men in the territory, all of the road men were returned soldiers. All three deputy returning officers for the territorial election held on 25 February 1920 were returned soldiers. Practically all of the new appointments made by the City of Dawson, with the exception of a three-member tax appeal board, were returned soldiers. ${ }^{93}$ Returned Yukoners were not the only ones asking for assistance. Pete Mournier was a returned soldier who requested assistance in December 1919. He had been discharged in Brockville in December 1918, having seen service in Canada. He arrived in Dawson on his way to Alaska and had no job, no friends, and was in need of food and clothing. ${ }^{94}$ These requests were a further drain on the territorial coffers.

In other parts of Canada, returned soldiers were granted land, but all agricultural and mining lands in the Yukon were under the direct supervision and control of the federal government, and nothing could be done by the Yukon Territory to settle ex-service men on the land..$^{95}$ Every discharged soldier was entitled to a resettlement loan if he could prove ownership of his land, but this was difficult for some Yukoners who had remote farms and had not bothered with the difficulty and expense of getting them surveyed. Partially disabled veteran Fred Envolsen had been living on his land for twelve years prior to his enlistment and had a fox farm with some large buildings. He had to ask for a letter of support from the gold commissioner so he could apply for a loan of $\$ 2,500$ to purchase stock and make improvements. ${ }^{96}$ A.A. Biggs had a different problem when he returned in the fall of 1919 to reopen his blacksmith shop. Biggs had enlisted in 1916, saw service in Canada, England, and France, and returned after three years absence to find there was little call for his outdated skills 
and that his shop was not outfitted for the type of work needed by modern miners. In this case, Yukoners did support one another and a solution was found when one of the better equipped shops in town arranged for Biggs to get work he could complete. ${ }^{97}$

Soldiers returned to find a very different Yukon from the one they had left. Work was scarce or non-existent, services in Dawson were inefficient and expensive, and the police had taken over from city and territorial crews to perform much of the maintenance. Money needed to support the large-scale mining had been diverted to other parts of the world, leaving many large concessions of mining claims tied up and dormant. Gold remained at a low fixed price and expenses were high. No one was optimistic about a bright future for the Yukon.

Was the war responsible? Not if you blame the decline in the labour force for Yukon's troubles. The large-scale mining companies had worked hard to use machines to replace men even before the war, and the processes just became more efficient when men were unavailable for work. The war certainly affected the price of commodities, but the richest ground ran out during the war years, and miners and financial backers moved away from placer gold as that price remained fixed. The development of hard rock mines took time and it was into the 1920s before the silver mines around Mayo were able to rejuvenate the Yukon economy. The Canadian government incurred debt during the war and saw no reason to support the gold rush infrastructure in the Yukon, especially with the loss in gold production. So yes, to some extent, and indirectly, the war was responsible for the Yukon's decline. The Klondike had to wait until the 1930s and a rise in the price of gold before the goldfields regained their energy.

\section{Author}

Sally Robinson is a public historian who has been working in the Yukon for almost forty years.

\section{Notes}

1. David R. Morrison, The Politics of the Yukon Territory 1898-1909 (Toronto: University of Toronto Press, 1968), 43; and Morris Zaslow, The Opening of the Canadian North, 1870-1914 (Toronto: McClelland and Stewart, 1971), 114-115.

2. Report of the Royal Northwest Mounted Police 1913 (Ottawa: Sessional Paper No. 28, 1914), 280.

3. Morrison, The Politics of the Yukon Territory, 87. 
4. David Neufeld and Patrick Habiluk, Make it Pay! Gold Dredge \#4: Klondike, Yukon, Canada (Missoula, Montana: Pictorial Histories Publishing, 1994), 18.

5. "Fair Financial, Yukon Gold," The Pittsburgh Gazette Times, Pittsburgh, 27 Mar 1908.

6. Report of the Royal Northwest Mounted Police 1913 (Ottawa: Sessional Paper No. 28, 1914), 280.

7. Morrison, The Politics of the Yukon Territory, 87.

8. Hal J. Guest, "A History of the City of Dawson, Yukon Territory 1896-1920" (Parks Canada Microfiche Report Series No 7, 1984), 281.

9. Richard G. Stuart, "Dawson City: Three Structural Histories” (Parks Canada Manuscript Report \#383, 1980), 96-97.

10. Hal J. Guest, "A History of the City of Dawson," 281.

11. Ibid., 186.

12. Stuart, "Dawson City: Three Structural Histories," 74.

13. Guest, "A History of the City of Dawson," 190-191.

14. Ibid., 174.

15. Greg Skuce, "The Klondike Mines Railway" in 100 Year History of White Pass Lodge No. 1, Skagway, Alaska, Yukon Lodge No. 45 Dawson City, Yukon: 1901-2000 (Whitehorse: Willow Printers, circa 2002), 174.

16. Guest, "A History of the City of Dawson," 278-79.

17. Report of the Royal Northwest Mounted Police (Ottawa: Occasional Paper No. 28, 1914), 226.

18. Ibid., 221.

19. Ibid., 226.

20. Ibid., 226.

21. Ibid., 226.

22. Robert McCandless, Yukon Wildlife, A Social History (Edmonton: University of Alberta Press, 1985), 113.

23. Ken S. Coates and William R. Morrison, Land of the Midnight Sun: A History of the Yukon (Edmonton: Hurtig, 1988), 159-160.

24. Guest, "A History of the City of Dawson," 279.

25. Ibid., 272.

26. Morrison, The Politics of the Yukon Territory, 92.

27. Report of the Royal Northwest Mounted Police, 1914, 7.

28. Report of the Royal Northwest Mounted Police, 1913, 279, 281.

29. Report of the Royal Northwest Mounted Police, 1914, 229.

30. Ibid., 229.

31. "Tells of the Yukon Boys in Victoria," Dawson Daily News, 20 Nov 1914.

32. The Yukon Territory, 1926 (Department of the Interior, Northwest Territories and Yukon Branch, 1926), 115

33. "Decision is Rendered on Big Law Suit," Dawson Daily News, 23 Nov 1914.

34. The Yukon Territory, 1926 (Department of the Interior, Northwest Territories and Yukon Branch, 1926), 115 
35. Report of the Royal Northwest Mounted Police, 1916 (Ottawa: Sessional Paper No. 28. 1917), 308-309.

36. Lewis Green, The Gold Hustlers (Anchorage: Alaska Northwest Publishing, 1977), 299-305.

37. Report of the Royal Northwest Mounted Police, 1916, 308-309.

38. Report of the Royal Northwest Mounted Police, 1914, 221.

39. Report of the Royal Northwest Mounted Police, 1916, 308-309.

40. E.D. Kindle, "Copper and Iron Resources, Whitehorse Copper Belt, Yukon Territory" (Geological Survey of Canada Paper 63-41, 1964), 30.

41. Report of the Royal Northwest Mounted Police, 1915 (Ottawa: Sessional Paper No. 28, 1915), 249-250.

42. Edward F. Bush, Banking in the Klondike 1898-1968 (Parks Canada Manuscript Report \#118, 1973), 3, 116.

43. Report of the Royal Northwest Mounted Police, 1915, 233.

44. Report of the Royal Northwest Mounted Police, 1916, 301.

45. Report of the Royal Northwest Mounted Police, 1915, 233.

46. Report of the Royal Northwest Mounted Police, 1916, 301.

47. Ibid., 301.

48. Walter R. Hamilton, The Yukon Story (Vancouver: Mitchell Press, 1964), 142.

49. Welch farmed at Thom's location just downstream from Minto Landing between 1903 and 1916: Mike Rourke, Yukon River: Marsh Lake to Dawson City (Houston B.C.: Rivers North, 1997), 113.

50. Frank G. Carpenter, "Farming in the Yukon: The Story of Chicken Billy and his Ten-Thousand-Dollar Potato Patch." The Toledo Weekly Blade, Toledo, Ohio, 13 Jul 1916.

51. Report of the Royal Northwest Mounted Police, 1916, 301.

52. Ibid., 307.

53. Ibid., 309

54. Margaret E. Archibald, "A Structural History of the Administration Building, Dawson, Yukon Territory" (Parks Canada Manuscript Report Number 217, 1977), 48.

55. Alaska Yukon Gazetteers 1901 to 1912 Index. Rasmussen Library.

56. John Gould, “A Short Bit of History: Dawson Legion No.1.” Unpublished.

57. Yukon Archives, GOV 1654, f.29600-G.

58. “Yukoners at the Front in the Great War," Dawson Daily News, 17 Aug 1915.

59. Report of the Royal Northwest Mounted Police, 1916, 309.

60. Ibid., 309.

61. Ibid., 312.

62. Letter from Gold Commissioner to Glacier Creek Mining Recorder, 13 Sep 1920. Yukon Archives GOV 1654, f.29600-B 7(7).

63. Report of the Royal Northwest Mounted Police, 1916, 303, 310.

64. Ibid., 303. 
65. Norman E. Kagan, "Pelly Pioneers at Ross River." Alaska Geographic, Vol. 25, No. 2, 1998: 92-94.

66. “A Yukon Pioneer," The Klondike Sun, Dawson City, 27 Mar 2001.

67. Letters from Garnett Watt to George M. Lindsay, 6 May 1918, and Garnett Watt to George Howes, 17 Sep 1918, Yukon Archives Watt family fonds 82/196 MSS 24 - MSS 25. Watt brother's papers, Box XVI.

68. Green, The Gold Hustlers, 299.

69. Hal J. Guest, "A Socioeconomic History of the Klondike Goldfields, 18961966, Part B" (Parks Canada Manuscript \#181), 276.

70. Report of the Royal Northwest Mounted Police, 1916, 301.

71. Report of the Royal Northwest Mounted Police for the year ended September 30, 1917 (Ottawa: Sessional Paper No. 28, 1918), 8-9.

72. Ibid., 8-9.

73. Guest, "A History of the City of Dawson," 100, 134.

74. Archibald, "A Structural History of the Administration Building, Dawson, Yukon Territory," 52.

75. Guest, "A History of the City of Dawson," 93-94.

76. Murray Eads story in Betty O'Keefe and Ian MacDonald, The Final Voyage of the Princess Sophia: Did They All Have to Die? (Surrey BC: Heritage House, 1998), 56; Les McLauglin, "Was Dan McGrew an American?" The Whitehorse Star, 15 Jun 2001; and “John Zaccarelli," Yukon Nuggets, 1918, http:// hougengroup.com/yukon-history/yukon-nuggets/year/1918

77. Most of the miners left the Wheaton River area near Carcross and the Post Office closed (McConnell Roadhouse, Yukon Historic Sites file). By the close of 1915, Duncan Creek had produced about $\$ 75,000$ but many of the miners left for the First World War: Elaine Ash, "In their Honour," Shakat (Whitehorse) Summer Journal, 1988, 47-48.

78. "Demobilisation and Discharge," The Long, Long Trail, http://www.19141918.net/demobilisation.htm

79. Yukon Archives, GOV 1654, 1(5).

80. Report from the Department of Soldiers' Civil Re-establishment dated 30 Jun 1920, Yukon Archives, GOV 1654, f.29600-G.

81. Letter from Controller H.H. Rowatt to Commissioner George Black, 21 Dec 1914, Yukon Archives GOV 1654,f.29600-B.

82. Yukon Archives GOV 1654,f.29600-B 2(7).

83. Letter from the Controller, Department of the Interior to the Yukon Gold Commissioner, 25 Mar 1920, Yukon Archives GOV 1654, f.29600-B 6(7).

84. Letter from the Department of the Interior, copy to the Gold Commissioner, Yukon Archives GOV 1654, f.29600-B 6(7).

85. Letter from the Controller, Department of the Interior, 7 Apr 1919, Yukon Archives GOV 1654, f.29600-B 6(7); and a letter from the Gold Commissioner, 6 Jul 1920, Yukon Archives GOV 1654, f.29600-B 6(7). 
86. Letter from Gold Commissioner to Superintendent Rowatt, 19 Feb 1921, Yukon Archives GOV 1654, f.29600-B 7(7).

87. Letter from the Controller, Department of the Interior to the Gold Commissioner, 19 Nov 1919, Yukon Archives GOV 1654, f.29600-B 6(7).

88. Letter dated 19 Jun 1918, Yukon Archives, GOV 1654, 1(5).

89. Letter dated 7 Oct 1918, Yukon Archives, GOV 1654, 1(5).

90. Letter dated 8 Jul 1918, Yukon Archives, GOV 1654, 1(5).

91. For example, positions in the Gold Commissioner's office were left vacant after the departure of James Mackinnon and Anthony Blaikie with Boyle's contingent in 1914. "Change in Work Since Boys Departed," Dawson Daily News, 13 Oct 1914.

92. Yukon Archives, GOV 1654, 1(5).

93. Yukon Archives, GOV 1654, f.29600-G.

94. Yukon Archives, GOV 1654 1(5).

95. Letter from the Gold Commissioner to Edmond Buron, 26 Apr 1918, Yukon Archives, GOV 1654, 1(5).

96. Letter to the Gold Commissioner, 28 Aug 1919, Yukon Archives, GOV 1654, $1(5)$.

97. Letter March 1920, Yukon Archives, GOV 1654, 1(5). 